九州大学学術情報リポジトリ

Kyushu University Institutional Repository

\title{
DESCRIPTIONS OF MICROSETIA SEXGUTTELLA THUNBERG AND ITS ALLIED NEW SPECIES FROM JAPAN (Lepidoptera, Gelechi idae)
}

Kuroko, Hiroshi

https://doi.org/10.5109/2346

出版情報: ESAKIA. 3，pp.1-9，1961-08-05. Hikosan biological laboratory，Faculty of Agriculture, Kyushu University バージョン :

権利関係 : 


\section{DESCRIPTIONS OF MICROSETIA SEXGUTTELLA THUNBERG AND ITS ALLIED NEW SPECIES FROM JAPAN*} (Lepidoptera, Gelechiidae)

BY

\section{Hiroshi Kuroko}

In summer of 1956, I sent several specimens of Microsetia to Prof. Dr. E. M. Hering of Berlin Zoological Museum for identification. These specimens were bred by me from Achyranthes japonica Nakai. Prof. Dr. Hering immediately wrote me as follows: " at a glance your specimens of Microsetia from Achyranthes seem quite similar to M.sexguttella Thunberg. But the shape of the mine is very much different between the specimens of leaves sent by you and those collected by me in Germany. Therefore, I think your species is specifically different from ours. I recommend you to make a comparison of the genitalia." Prof. Dr. Hering was so kind as to spare me the European specimens of $\mathbf{M}$. sexguttella. My study on the genitalia of Japanese and European specimens revealed that they are very similar to each other. Thus, I felt some hesitation in the separation of these specimens. Fortunately, however, Prof. Dr. Hering sent me some alcoholic specimens of the larvae of $\mathbf{M}$. sexguttella for comparison. Finally, I could find distinct differences on the larval characters between $M$. sexguttella and Japanese species, and confirm that the Japanese species may represent a new species.

Besides, I received a specimen of Microsetia from Mr. T. Kumata of Hokkaido University in 1958, and I found that this specimen was nothing but Microsetia sexguttella Thunberg.

In the larval description, the nomenclature used for the setae is that of Hinton (1946).

I wish to express my hearty thanks to Prof. K. Yasumatsu of Kyushu University for his kind guidance and constant encouragement; to Prof. Dr. E. M.

* Contribution Ser. 2, No. 12, Hikosan Biological Laboratory, Kyushu University, Hikosan.

Contribution Ser. 2, No. 100, Entomological Laboratory, Kyushu University, Fukuoka. 
Hering of the Berlin Zoological Museum for his kind assistance and direction in the course of the present study; to $\operatorname{Dr}$ A. Kawada and Mr. T. Kumata of Hokkaido University for the gift of valuable specimens.

\section{Microsetia sexguttella (Thunberg)}

Tinea sexguttella Thunberg, Ins. Suecia (7): 88, 1794.

Tinea stipella Hübner, Samml. Eur. Schmett. Tin., f. 138, 1796.

§. $9 \mathrm{~mm}$. Head and thorax bronzy-fuscous, face silvery-bronzy. Palpi not

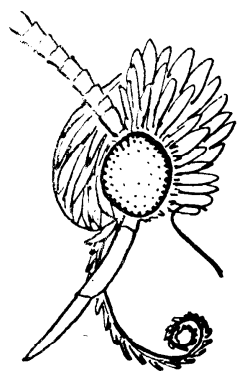

Fig. 1. Head of Microsetia, lateral view. ascending, rather straight, terminal joint pointed ; dark fuscous with white scales on upper side of each joint. Antennae $3 / 4$ greyish fuscous in male. Abdomen bronzy-fuscous above and silverywhite beneath.

Forewings dark greyish-fuscous with bronzy lusters, apex of each scale black; markings yellow; a rather broad oblique transverse fascia from $1 / 5$ of dorsum, not reaching costal margin, a trapezoidal or subtriangular spot at middle of dorsum and a round spot on disc of $2 / 3$; surrounding of the basal fascia and discal spot rather enclosed by lustrous greyish-leaden scales; an ill-defined pale ochreous spot on tornus and another at $3 / 4$ of costa. Cilia grey, dotted with blackish scales, apex of cilia whitish. Hind. wings elongate-trapezoidal, apex produced and pointed; greyish.fuscous; cilia greyish-fuscous.

Male genitalia: Uncus weakly sclerotized; gnathos barbed globular, with a cranck; valve elongated, parallel-sided, apex rounded; sacculus rather sclerotized and roundish quadrate, with dense fine spines on the apex, outside of the fine spines are arranged blackish short coarse spines which are changeable from 7 to 15 ; saccus triangular; aedoeagus narrowed at apex, its basal portion forming a round coecum penis. The genitalia of both sexes were illustrated by Pierce \& Metcalfe (1935: 6, P1. 3)

Specimen examined: 1§, Sapporo, Hokkaido, 12 Sept. 1957, bred by Mr. T. Kumata from Chenopodium album Linné var. centrorubrum Makino.

Host plants: Chenopodiaceae, Chenopodium album Linne var. centrorubrum Makino (Jap. name: Akaza), C. album Linne, Atriplex sp. ; Amaranthacese, Amaranthus $\mathrm{sp}$.

Distribution : Japan (Hokkaido), S.\& C. Europe, Asia Minor, S. Africa, Canada.

This species was identified by comparison with two European specimens which were sent to me from Prof. Hering. It is reported that the larvae of this species form blotch mines on leaves of Chenopodium album Linne and Atrip lex s p. which are common in Europe. Prof. Hering informed me that he bred it from Amaranthus sp. This species spreads in England, Germany, Belgium, Switzerland, Austria, Hungary, France, Corsica, Italy, Greece, Turky 
and Natal. Accor*ding to the informati on from Prof. Hering this species occurs in Canada. This is the first record of the species in Japan.

\section{Microsetia heringi sp. nov.}

of. 7-8.5 mm. Head, thorax and palpi bronzy-fuscous, face silvery-bronzy. Antennae $3 / 4$ in both sexes, dark fuscous. Abdomen bronzy-fuscous above and silvery-white beneath.

Forewings dark greyish fuscous with reddish lusters in some lights, apex of each scale black; markings yellowish-orange; basal fascia reaching costal margin, dorsal and discal spots present as in the preceding species; surroundings of the basal fascia and discal spot enclosed by bluish-leaden scales; tornal and costal spots indistinct; cilia grey, dotted with blackish scales, apex whitish. Hindwings and cilia greyish-fuscous.

This new species is most closely related to $M$.sexguttella Thunberg, but the markings are much more tinged with orange and the basal fascia reaching costal margin. Venation of the present species is the same as that of $M$. sexguttella Thunberg.

Male genitalia : Differential characters from M.sexguttella Thunberg are as follows: sacculus nearly rhombic and the apical fine spines more acutely pointed; aedoeagus shorter, coecum penis forming two lobes. Number of coarse spines on sacculus from 10 to 14.

Female genitalia : Ovipositor sclerotized, two dark semicircular pads set with long setae; apophysis anterioris and apophysis posterioris very short and the former shorter than the latter; ostium semicircular narrow plate ; ductus bursae with densely minute spines; signum absent. I could not find any difference between the female genitalia of this species and that of sexguttella Thunberg, except the former being smaller than the latter.

Distribution : Japan (Honshu, Kyushu).

Holotype: ô, Mt. Hikosan, N. Kyushu, 26 Aug. 1957 (H. Kuroko).

Allotype: o, the same as holotype, 2 June 1954 (H. Kuroko).

Paratypes: 2 \%o, the same as holotype, 24 \& 28 May 1954 ; 1 ; 2 June 1954; 1 . 30 July 1955 ; 1 \%, 25 Aug. 1955; 3 ŝै, 7 우, 26-31 Aug. 1357 (H. Kuroko), bred from Achyranthes japonica Nakai. The above types are deposited in the collection of the Entomological Laboratory, Kyushu University. 1\%, 30 May 1938; 3‡क, 6-10 June 1938, these were bred by Dr. A. Kawada in Tokyo from Achyranthes japonica $\mathrm{Nakai}$ and are deposited in the National Institute of Agricultural Sciences.

I dedicate this specific name to Prof. E. M. Hering for his kind direction in my present study.

Egg. The egg is laid on the under surface of the leaf, usually close to a slender rib. About $0.3 \mathrm{~mm}$. in length and $0.2 \mathrm{~mm}$. in width, short elliptical, flattened below and convex above, tender, transparent but with pearly lusters, minutely faceted. 
Larva (Figs. 2, 3, 14-21). First instar: Head pale black to pale blackishbrown; body cylindrical, pale yellow or whitish, tinged with slightly pale brown on dorsal area; thoracic legs concolorous with the body; prolegs absent.

Second instar: Head pale brown; body whitish, with a pale brown transverse stripe on each segment except thorax; prothoracic shield blackish brown ; thoracic legs pale black ; prolegs absent.

Third instar: The coloration is the same as

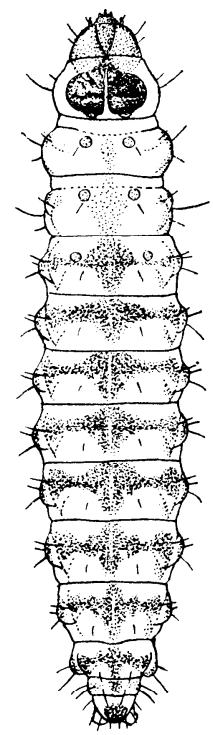

Fig. 2. Mature larva of

Microsetiaheringi sp. nov. in the previous instar, but prothoracic shield darker, transverse stripes tinged with blackish brown; prolegs present on 3rd-6th and 10th abdominal segments, but chrochets undeveioped.

Fourth instar (last instar): Head blackish brown; body cylindrical, faintly pale yellow dark green, alimentary canal seen through the cuticle; elliptical blackish brown shield plate divided into two parts on meson; a pair of yellowish orange to reddish orange subdorsal spots (diam., $0.08 \mathrm{~mm}$. to $0.14 \mathrm{~mm}$.) on mesoand metathorax respectively, sometimes on prothorax and 1st abdominal segment; purplish brown patches placed on dorsal and supraspiracular areas of meso- and metathorax, and the same colored transverse stripes, dilated on dorsal and supraspiracular areas, are seen on abdominal segments except last segment ; anal plate pale black; thoracic legs pale yellowish brown with coxal plates dark brown; peritreme of spiracles brown; ventral prolegs long and slender, with brownish crochets; surface of cuticle densely, microscopically spined.

Table 1. Width of head and length of body in each instar.

\begin{tabular}{cc|c}
\hline \hline Instar & Width of head (in mm.) & Length of body (in mm.) \\
\hline 1 & 0.115 & $0.4-1.3$ \\
2 & 0.19 & $1.3-1.8$ \\
3 & $0.3-0.35$ & $1.5-4.0$ \\
4 & $0.45-0.50$ & $3.5-6.0$ \\
\hline
\end{tabular}

Head-capsule rounded and depressed; dorsal side projecting over ventral $2 / 5$; apex of adfrontals almost reaching vertical triangle; fronto-clypeus extending about $5 / 6$ of distance to vertical triangle; 2 nd joint of antenna the longest among antennal joints ; labrum with three pairs of median and lateral setae on dorsal side respectively, setae L3 and M3 very broad, three pairs of spindleshaped flattened epipharyngeal setae and a pair of punctures on ventral side; 
mandible with five teeth, setting only one mandibular seta; spinneret very prolonged ; lacinia with two two-jointed digiti and three setae.

Ventral prolegs with 2-6 crochets, uniordinal, and anal prolegs usually without crochets, but rarely with a single crochet. Spiracles circular; spiracles of prothorax and 8th abdominal segment slightly larger than those of Ist-7th abdominal segments.

Chaetotaxy : Cranial setae as shown in Plate 3, fig. 14. Clypeal seta C2 much longer than $\mathrm{Cl}$; adfrontal setae represented by only a pair of $\mathrm{Fal}$; $\mathrm{A} 3$ the
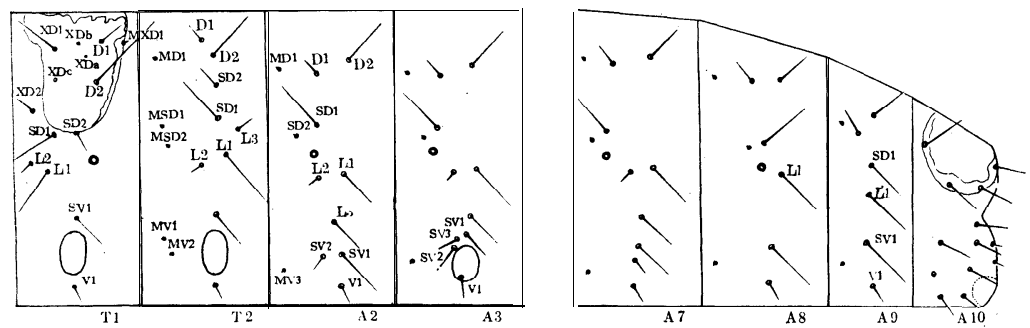

Fig. 3. Chaetotaxy of pro- and mesothorax, 2nd, 3rd,7th, 8th, 9th and 10th abdomonal segments respectively. Mature larva of Microsetia heringi sp. nov.

longest of all cranial setae; 01 cephalad and 02 ventrad from 1st ocellus, $\mathrm{O} 3$ absent; SO2 slightly ventrad from a line joining 5th ocellus and 6th ocellus and nearer to the latter than to the former; L1 very minute and caudad from $\mathrm{A} 3$, in a horizontal line; puncture $\mathrm{Pb}$ dorsad from a line joining $\mathrm{P} 1$ and $\mathrm{P} 2, \mathrm{~Pa}$ absent; Va and V3 absent; Ga equidistant and slightly dorsad from G1 and G2. Chaetotaxy of thorax and abdomen as shown in Fig. 3. On prothorax L3 absent, this character is exceptional in this family ; MXD1 present but MV group absent; SV group unisetose. Chaetotaxy of metathorax like that of mesothorax. On meso- and metathorax D1 dorsad from D2 ; SV group unisetose ; MV3 absent; on abdomen D1 ventrad from D2; on 8th and 9th abdominal segments L2 and L3 absent; SV group of Ist, 8th and 9th abdominal segments unisetose, of 2nd and 7th bisetose, and of 3rd-6th trisetose; V1 setting on mesal side on swelling of prolegs on 3rd-6th abdominal segments.

The larva of $\mathbf{M}$. sexguttella Thunberg is very similar to that of this new species, but differs in the following characters: the setae MI and M2 of labrum broadend (those of the latter are slender as shown in Plate 3, figs. 18 \& 22).

Cocoon. When the larva is full fed, it creeps out from a slit formed on the underside of the leaf, and proceeds in search of a convenient site for cocooning. It makes a cocoon in a crevice or between two dead leaves.

The cocoon is oval, somewhat flattened; close and strong; whitish-ochreous. The size about 4-5 $\mathrm{mm}$. in length, and 2.4-3.0 $\mathrm{mm}$. in width.

Pupa (Fig. 4). About 2.9-3.3 mm. in length, $1.1-1.2 \mathrm{~mm}$. in width, and 0.9-1.0 $\mathrm{mm}$. in thickness. The body is glossy light brown to brown; longish oval, somewhat flattened. A pex of head rounded; dorsal area convex, and ventral 
area, in lateral aspect, somewhat flattened; entirely with shallow punctures and whitish short hairs (about $10 \mu$ in length). Fronto-clypeal suture absent; clypeo-
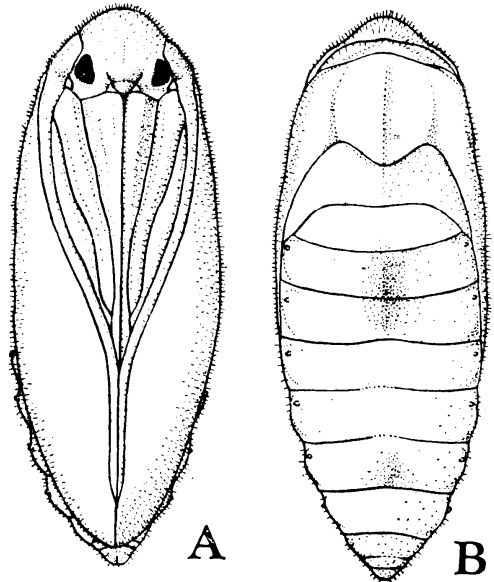

Fig. 4. Pupa of Microsetiaheringi sp. nov. A. Ventral view. B. Dorsal view. labral suture indistinct; pilifers adjacent to lateral margin of labrum; labial palpi invisible; maxillary palpi present, but never reaching proximo-lateral angles of maxillae; maxillae extending beyond tips of mesothoracic legs; antennae not reaching tips of the wings in both sexes and not separated at those distal ends. Forewings extending to caudal margin of 9th abdominal segment; mesothoracic legs extending to nearly half the distance between tips of prothoracic legs and maxillae. Hindwings entirely concealed by forewings ; metathoracic legs invisible. Spiracles slightly protruded and surroundings of spiracles moderately swollen on 2nd8th abdominal segments; 10th abdominal segment without any cremaster or setae.

\section{Biological notes}

Host plant : Amaranthaceae, Achyranthes japonica (Miq.) Nakai (Jap. name : Hikage-inokozuchi).

The larva, as soon as hatched, bores into the leaf, and commences to make its irregular whitish-green wavy linear mine, in which black frasses are deposited in a very slender line; the larva almost always attains the edge of the leaf; after the second moult, its mine is broadened partly; in the last instar, it makes a whitish-green blotch mine, in which greenish-black frasses are placed somewhat in a series of arcs of circles or zigzag line, and greenish grains are figured by feeding tracks. Usually one mine is found on a single leaf, sometimes two to five mines being found. The mine is visible from either side of the leaf, because it is in full depth. When the leaf withered, the larva leaves the old leaf and migrates to the other fresh leaf through the underside.

Mine of the first instar: linear, about $9 \mathrm{~mm}$. in length, and $0.1 \mathrm{~mm}$. in width.

Mine of the second instar: linear, about $16 \mathrm{~mm}$. in length, and $0.3-0.4 \mathrm{~mm}$. in width.

Mine of the third instar: linear, but partly blotch, about $24 \mathrm{~mm}$. in length, and $2.5 \mathrm{~mm}$. in width at the broadest portion.

Mine of the fourth instar: blotch, 224 to $375 \mathrm{~mm}$ ? in area. 
The entire larval period is about twenty days in the first generation.

The mines of $\boldsymbol{M}$. sexguttella Thunberg are very different from those of this species, and are whitish blotch from the beginning and containing a greenish-black patch of frasses.

There are two broods in a year on Mt. Hikosan, N. Kyushu; the larvae feed in July, and from the end of September to the beginning of November, and the adults appear from August to September and from the end of May to June as shown in Table 2.

A last instar larva which was forced to mine in the leaf of Chenopodium album Linné var. centrorubrum Makino, almost reached to maturity and the adult appeared on June 12th, 1958. The larvae which bored with difficulty into the leaves of Amaranths

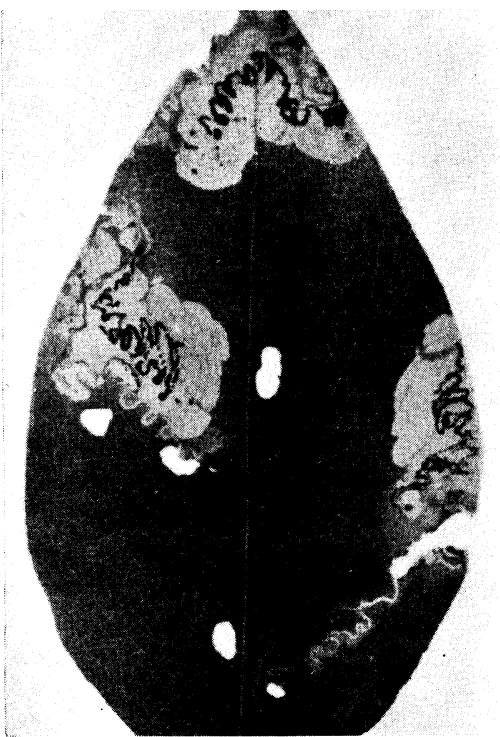

Filg. 5. A leaf of Achyranthes japonica Nakai mined by larvae of Microsetia hering $i$ sp. nov.

ascendens Loisel. and Beta vulgaris Linné var. Cicla Linné, slightly extended their mines, but the larvae could not attain maturity, and died in a short time.

Table 2. Distribution of stages in a year (mainly observed in the field).

\begin{tabular}{|c|c|c|c|c|c|c|c|c|c|}
\hline $\begin{array}{l}\text { Months } \\
\text { Stages }\end{array}$ & $1-4$ & 5 & 6 & 7 & 8 & 9 & 10 & 11 & 12 \\
\hline Egg & & & 0 & & & - & & & \\
\hline Larva & & & & $\begin{array}{lll}0 & 0 & 0\end{array}$ & 0 & 0 & 000 & 0 & \\
\hline Pupa & $\begin{array}{lll}0 & 0 & 0\end{array}$ & 00 & & 0 & $\begin{array}{lll}0 & 0 & 0\end{array}$ & & & 00 & $\begin{array}{lll}0 & 0 & 0\end{array}$ \\
\hline Adult & & & 00 & & 00 & 00 & & & \\
\hline
\end{tabular}

\section{References}

Fracker, S. B., 1915, The classification of lepidopterous larvae. Illinois Biol. Monogr., $2: 83$.

Frey, II., 1880, Die Lepidopteren der Schweiz : 369, Leipzig.

Gozmány, L., 1958, Fauna Hungariae. Microlepidoptera IV: 268-269, Budapest. Hering, E. M., 1951, Biology of the leaf miners, 'S-Gravenhage, Netherlands. 
Hinton, H. E., 1946, On the homology and nomenclature of the setae of lepidopterous larvae. Trans. R. Ent. Soc. Lond., 97: 1-37, 24 figs.

Lhomme, L., 1935, Catalogue des Lépidoptères de France et de Belgique, 2: 560.

Meyrick, E., 1895, A handbook of British Lepidoptera: 574, London. , 1925, Genera Insectorum, Fam. Gelechiadae, fasc. 184: 47, Bruxelles. 1927, A revised handbook of British Lepidoptera: 612, London.

Mosher,' E., 1916, A classification of the Lepidoptera based on characters of pupa. Bull. Illinois St. Lab. Nat. Hist., 12: 101-103.

Peterson, A., 1951, Larvae of insects, part 1: 88, figs. 8, 15-17, Columbus, Ohio.

Pierce, F. N. \& Metcalfe, J. W., 1935, The genitalia of the Tineid families of the Lepidoptera of the British Island :6, Pl. 3, Oundle.

Spuler, A., 1910, Die Schmetterlinge Europas, II: 376, Stuttgart.

Stainton, H. T., 1865; The natural history of the Tineina, 9: 246-260, London.

Staudinger, 0. \& Rebel, H., 1901, Catalog der Lepidopteren des Palaearktischen Faunengebietes, II: 156, Berlin.

Stephens, J. F., 1834, Illustrations of British Entomology (Haust. 4) : 263-265. 
Explanation of Plates

Plate 1

Fig. 6. Microsetia sexguttella Thunberg (European specimen).

Fig. 7. Microsetia heringi sp. nov.

$$
\text { Plate } 2
$$

Figs. 8-11. Microsetia heringi sp. nov.

(8) Male genitalia. (9) Valva and sacculus, lateral view. (10) Aedoeagus.

(11) Female genitalia.

Figs. 12 \& 13. Microsetia sexguttella Thunberg, Japanese specimen. (12) Valva and sacculus, lateral view. (13) Aedoeagus.

\section{Plate 3}

Figs. 14-21. Microsetia heringi sp. nov., mature larva.

(14) Chaetotaxy of head. (15) Ventral view of right mandible. (16) Dorsal view of right antenna. (17) Ventral view of labium and left maxilla. (18) Labrum, the left in dorsal view and the right in ventral view. (19) Right prothoracic leg. (20) Right ventral proleg of 6th abdominal segment. (21) Microtrichia on dorsum of 6th abdominal segment.

Fig. 22. Labrum of larva of Microsetia sexguttella Thunberg, the left in dorsal view and the right in ventral view (European specimen). 
Esakia No. 3, 1961
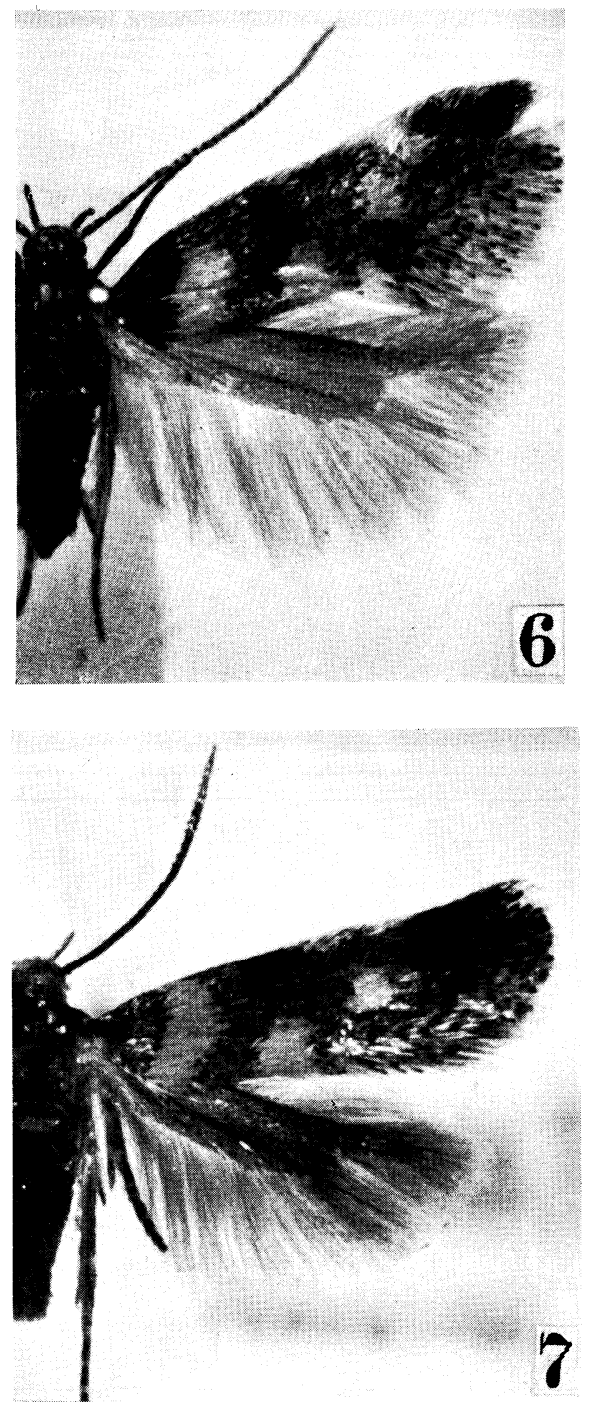

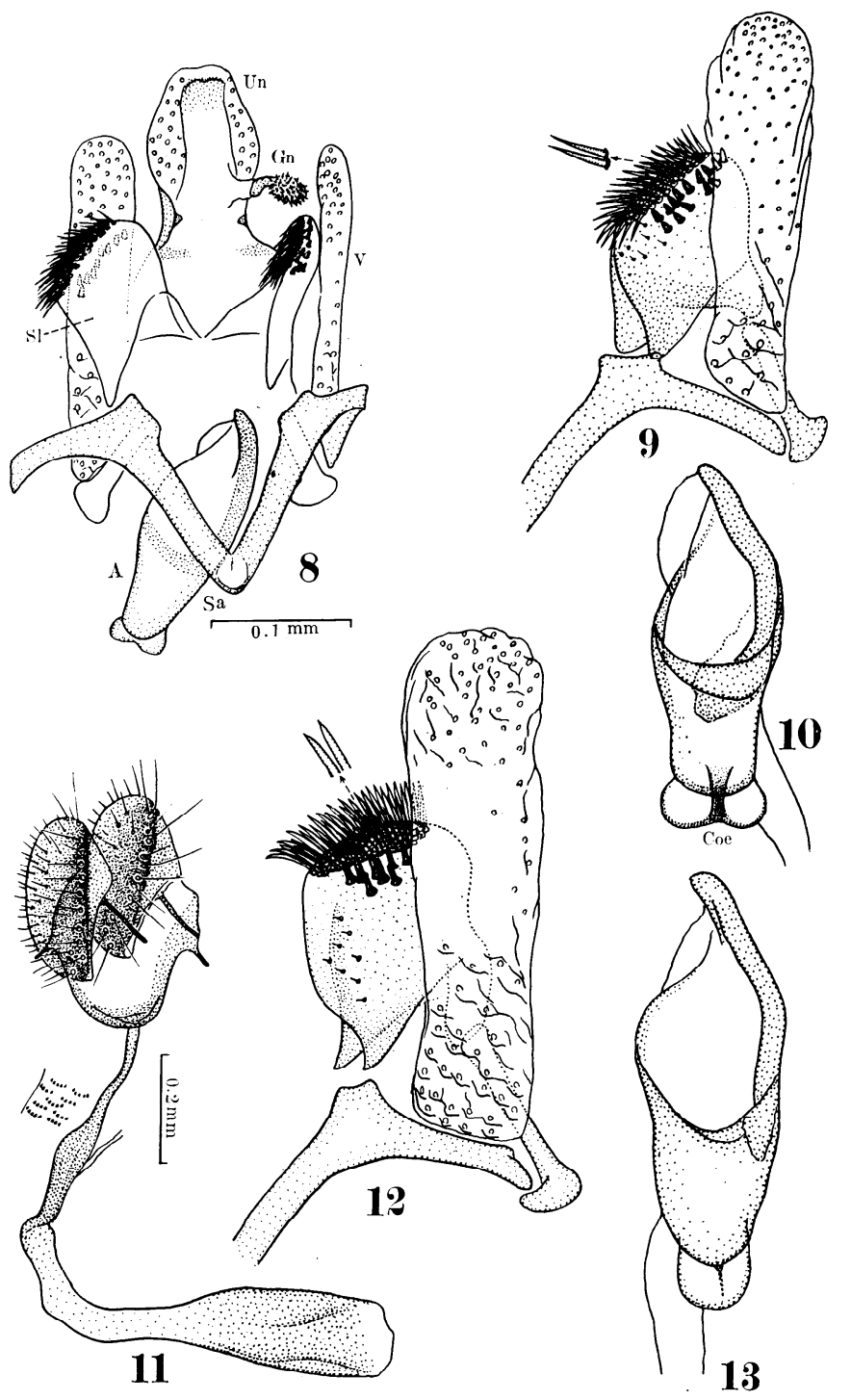


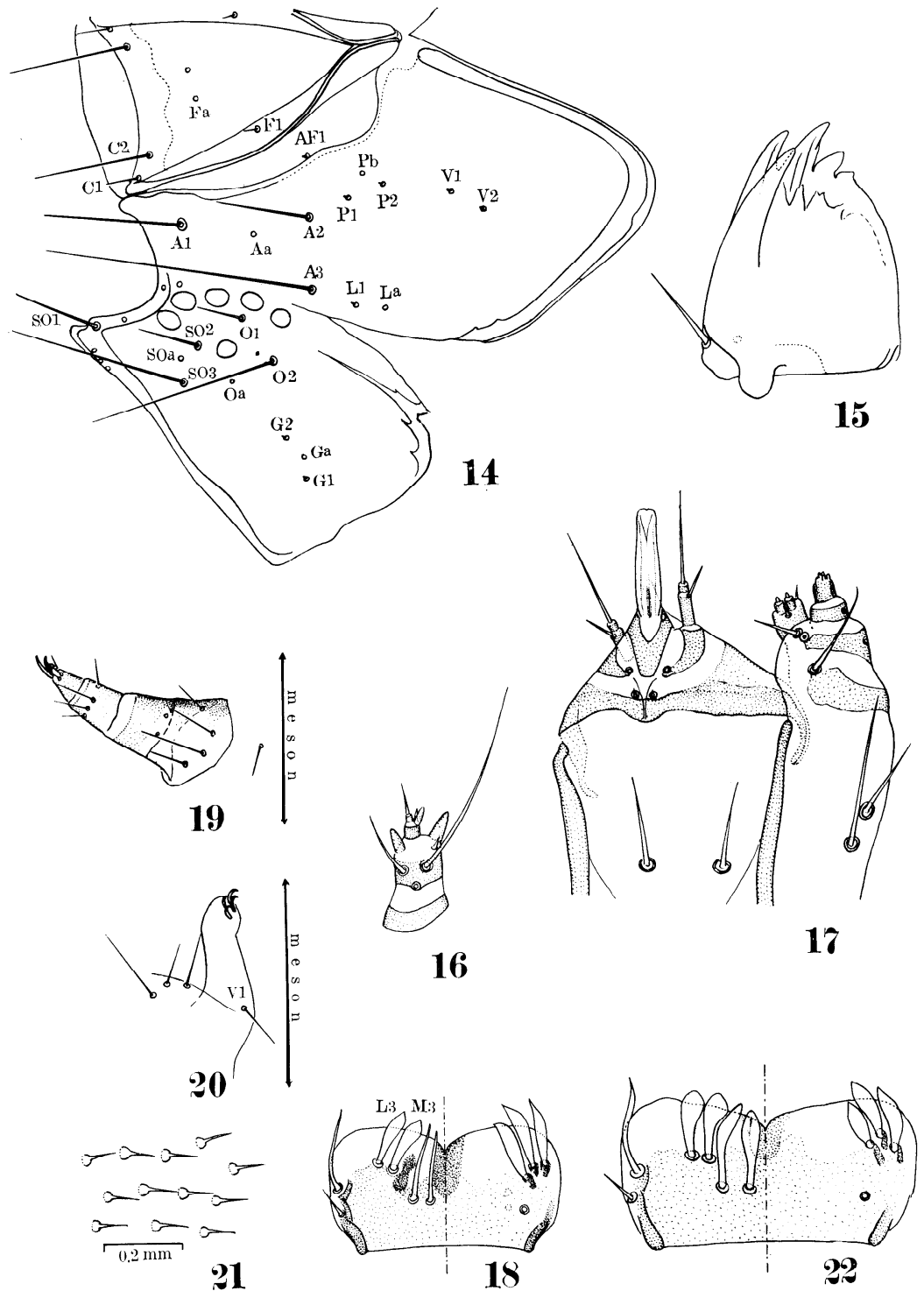

